\title{
Development and Implementation of Blended Learning (PPBL) in Block 3B. Midwifery Care During Childbirth
}

\author{
Yulizawati, S.ST., M.Keb ${ }^{1, *}$ Miranie Safaringga, S.ST., M.Keb ${ }^{2}$ \\ ${ }^{l}$ Undergraduate Midwifery Program Faculty of Medicine Andalas University, Jl. Niaga No.156, Belakang Pondok, \\ Padang, West Sumatra 25134, Indonesia \\ *Corresponding author.Email:yulizawati@med.unand.ac.id,miraniesafaringga@med.unand.ac.id
}

\begin{abstract}
Block 3.B, which is entitled Midwifery Care for normal delivery, is the second block that must be studied by third semester students in the Undergraduate Program of Midwifery, Faculty of Medicine, Andalas University. This study uses a comparative study. Bivariate analysis was categorical correlative using t-test, for hypothesis testing with Mc.Nemar, multivariate analysis using logistic regression analysis. The study population was all students of the S1 Midwifery Study Program, Faculty of Medicine, Andalas University semester III. The results of calculations before applying the student center learning (CTL) learning method with a problem-based learning (PBL) approach through blended learning, The majority of students scored in the range 55-59 with a total of 9 people (20\%), while after being given treatment the student scores increased with the majority in the range $75-79$, namely 16 people (36\%). Based on the results of the discussion above, it can be concluded that blended learning has a positive impact on increasing the value and motivation of student learning in Block3B.
\end{abstract}

Keywords: Midwifery Care During Childbirth, Development and Implementation of Blended Learning

\section{INTRODUCTION}

Block 3.B, which is entitled Midwifery Care for normal delivery, is the second block that must be studied by third semester students in the Undergraduate Study Program of Midwifery, Faculty of Medicine, Andalas University. Students who take part in the learning in this course block give students the opportunity to understand the concepts, changes and mechanisms of normal delivery, basic needs of mothers in labor, implementation of assessments of mothers in labor and neonates, determining planning, management and evaluation of labor, as well as documenting midwifery care during childbirth. normal and newborn. Thus mastery of the material in Block $3 \mathrm{~B}$ is important, because it will provide provisions for students in providing midwifery care to mothers who give birth.

Block 3B, entitled Midwifery Care for childbirth, is a block that must be studied by third semester students in the Undergraduate Study Program of Midwifery, Faculty of Medicine, Andalas University. Students who take part in learning in this block have finished taking blocks 1A, IB, IC, 2A, 2B, 2C and 3A. They already know briefly about midwife education in block $3 \mathrm{~A}$, to become a midwife it is very important that they learn this concept of midwifery. Block 3B is important to study because experience shows that when new students choose to major in midwifery in college, they do not necessarily understand how a midwife serves clients. This is because when choosing a major after finishing high school.

The learning method in higher education uses the adult learning method. This method has a different approach, scope, goals and strategies from education in secondary schools. Studying in higher education, especially in medical and health sciences, emphasizes education in a sustainable and lifelong manner.

Midwifery education uses a new paradigm, namely the PBL (Problem Based Learning) method, where at the basic level students must master learning techniques and it is hoped that later they will be able to learn continuously throughout their lives and are also required to master communication techniques, ranging from interpersonal communication to communicating. with various parties (doctors and other health workers and other non-health workers) either verbally or nonverbally or using information technology. Mastery of this basic level of education is absolute, because it is a prerequisite for a student to be able to continue learning at the next stage, namely learning block 3.B Midwifery Care in childbirth. 
Thus mastery of the material in Block 3B is important, because it will provide provisions for students in the formation of a thinking process and a basis for professional behavior in providing effective and comprehensive Midwifery Care for pregnant women in the future.

\section{METHODS}

This study uses a comparative study. Bivariate analysis was categorical correlative using t-test, for hypothesis testing with Mc.Nemar, multivariate analysis using logistic regression analysis.

The study population was all students of the S1 Midwifery Study Program, Faculty of Medicine, Andalas University semester III. The sample is a part or representative of the population studied. Based on a statistical approach, the sample size is determined by the statistical model that will be used to test the hypothesis. In this study, the statistical test to be used was the t-test for paired data using Mc.Nemar. The method of sampling is using total sampling.

The research stages include:

1. Determine the respondents to be sampled

2. Assess the respondent's ability

3. Using the right approach method

4. Reassess

5. Comparing the skills of respondents before and after.

The implementation of data collection was carried out by researchers. A sympathetic attitude and a good impression given by the interviewer is very important. The data obtained were then analyzed and hypothesis tested. Use the appropriate instrument. Data processing and data analysis using a computer through the following stages:

The questionnaires that have been collected are then checked for completeness including coding, upon completion of data collection to avoid errors. Then data entry was carried out using the Statistical Package for Social Science (SPSS) program for Windows version

14.0. Processing data with statistical methods, so it is expected that the data obtained is complete, clear, consistent and in accordance with the questions. Data analysis using the SPSS for windows version 14.0 program as follows:

1) Univariable Analysis: Analyzing the existing variables to determine the frequency distribution and average of each variable

2) Bivariable Analysis: Bivariable analysis, is an analysis of the results of the independent and dependent variables. Data analysis that is categorical ordinal can use $2 \times 2$ tables. Correlation using paired ttest with Mc. Nemar. The significance of the test results was determined based on the $\mathrm{p}$ value $<0.05$.

3) Multivariate Analysis: Multivariate analysis for the dependent and independent variables with ordinal categorical scale in this study is to use logistic regression analysis, to determine how strong the correlation is using the Spearman correlationtest.

The learning methods applied so far are

a. Tutorial.

Group discussion Lessons facilitated by a tutor are scheduled twice a week to discuss one scenario. Discussions are held in a structured manner using the seven jump method. If unable to attend for any reason, the student concerned must inform the tutor within $2 \times 24$ hours. Each group is required to make a tutorial discussion report in the format according to the seven jump step, except that step 6 does not need to be written down. The report is made and printed, then submitted to the academic department, besides that the report file is also sent before the tutorial on the first day of the next module to the email address:s1kebidananfkunand2014@gmail.com

b. Clinical Skills

Activities to acquire midwifery skills, ranging from communication, laboratory skills, procedural skills and diagnostic physical skills. This clinical skill is implemented three times a week according to a predetermined schedule. Each group will be guided by an instructor.

c. Practice

Activities carried out in the laboratory, which aim to increase understanding of the theory.

d. Plenary discussion

The purpose of this discussion is to synchronize and compare the group learning process to prevent groups from taking the wrong path. The group can pose unsolved problems and the facilitator will guide the discussion. This activity is held every week and is attended by related experts.

e. Introductory lecture

Lectures given by experts, which aim to provide guidance to students in learning a topic.

f. Consultation with facilitators / instructors / experts. Consultation with experts if necessary by making prior agreements. 


\section{g. Learn to be independent}

As an adult learner, you are expected to undertake independent study, a skill that is essential for your future career and development. These skills include knowing your own interests, finding more information from available learning resources, understanding information using different learning strategies and activities, assessing your own learning and identifying future learning needs. It is not enough to learn from lecture notes alone. Self-study is an essential feature of the PBL approach and learning should be regarded as an endless journey to obtain information. Summary of independent learning outcomes from various sources are recorded in books, so that every student must have an "independent study notebook". As the main reference in independent learning is the "learning objectives" which have been formulated together on the first day of the tutorial, but students can learn more outside the learning objectives according to their respective interests and curiosity.

\section{h. Small group discussion (DKK)}

This small group discussion aims to deepen understanding of the theory. This activity is carried out on a scheduled basis, twice a week to discuss predetermined topics. At DKK I Before the discussion, each student must prepare himself with material according to the topic to be discussed. The discussion is led by the group leader and recorded by the secretary who has been elected. The results of individual work and group discussions are left to the person in charge of the DKK. At DKK II each group presented the results of their discussion in front of the class attended by a supervisor who provided input and directed the presentation.

Learning Resources.

Learning sources include: textbooks, magazines and journals, the Internet (e-library), resource persons and laboratories.

Instructional Media.

The instructional media used are tutorial guides for students and tutors, practicum guides, CD ROMs, practicum preparations and demonstrations and clinical skills guides.

The assessments carried out in measuring student learning outcomes that are applied during this time are:

\section{Tutorial Assessment 20\% \\ 2. Written Test (MCQ) $60 \%$ \\ 3. Assessment assignments 20\%}

The assessments that will be carried out in measuring student learning outcomes that will be applied in the current Odd semester of 2020/2021 are:
1. Tutorial Assessment

(Presence, creativity, relevance, attitude)

2. Written Test (MCQ)

3. Assessment assignments

(Midwifery care management, DKK and plenary implementation which assesses aspects of attendance, creativity, relevance, attitude)

Integration of soft skills as a process assessment Tutorials (Presence, creativity, relevance, attitude)

$\rightarrow$ instrument development. In the MCQ assessment, a review item analysis is carried out. Integration of soft skills as a clinical skill assessment is communication, initiative, responsibility, sensitivity. $\rightarrow$ instrument development. Psychomotor assessment of clinical skills is carried out by improving existing instruments. Integration of soft skills as task assessment is the development of assessment instruments in small group discussions that include the following aspects:cooperation, responsibility, promotive interaction, trust, decision making, communication and conflict management.

The results of the $20 \%$ assignment assessment consisted of soft skills and cognitive assessments in the form of learning achievements from group discussions in each given topic each week. In this semester, the development of a group discussion implementation method with the STAD (Student Teams Achievement Division) type of cooperative learning method was also carried out. $\rightarrow$ instrument development

Examination requirements:

1. Students who will take written / practicum exams must follow the following requirements:

a. Minimum attendance in tutorial discussion activities is $80 \%$

b. Minimum attendance in plenary discussion activities is $80 \%$

c. Minimum attendance in clinical skills activities $80 \%$

d. Minimum attendance in practicum activities is $80 \%$

2. If they do not pass the written test, students will have the opportunity to take a remedial exam once at the end of the academic year concerned. If it still fails, the student concerned must repeat the Block.

a. The assessment provisions are based on the academic regulations of the 2011 Andalas University undergraduate program.

Methodology or strategy for Output Achievement

1) Learning Plan (RPB) Odd Semester 2020/2021 Blended Learning. 
Block Guidebook. The plan to change the contents of the previous RPB to a new RPB for Blended Learning is in the form of a plan to develop learning methods and assessment of e-learning that are effective in achieving learning outcomes. The development of learning methods and online assessments should provide the same or better results than conventional learning and assessment methods. The RPS / RPB will explain the selected learning activities, whether virtual synchronous or asynchronous (independent or collaborative) and appropriate technology media to achieve learning outcomes. The e-learning assessment of learning outcomes refers to SNPT No.3 of 2020 which includes an assessment of the process and results,

2) The proposed learning technology media is able to better replace conventional learning methods (effective and efficient) in achieving learning outcomes.

Learning technology media used is online media through I learn. Learning methods that can be used are group discussions, simulations, case studies, collaborative learning, cooperative learning, problembased learning, which can effectively facilitate the fulfillment of graduate learning outcomes. Learning forms and methods are chosen effectively to fit the characteristics of the course to achieve certain abilities determined in the course in a series of fulfillment of graduate learning outcomes. The forms of learning are: lectures, responses, tutorials, seminars or equivalent, practicum, studio practice, workshop practice, field practice and / or other equivalent forms of learning.

Learning Method Development Problem-based

learning method (PBL). Definitions:

Problem-based learning (PBL) is a learning strategy for students to learn together in a small group through two main learning activities, namely small group discussions facilitated by a tutor and independent learning.

\section{Description:}

PBL is a form of self-directed learning (SDL) which is more directed and structured. In contrast to pure SDL, students are given flexibility in determining the scope of the material being studied according to their interests. In PBL learning, the scope of learning is more focused and specific. The scope of learning in PBL is based on specific learning objectives that are detailed in the curriculum. The amount of time spent on the PBL process is also more limited than the amount of time spent on pure SDL. At SDL murni, students are given the flexibility to determine the amount of time they need to complete their inquiries, while in PBL students must complete the achievement of their learning objectives within the time frame set by the educational institution. On pure SDL, students can work individually based on their respective interests, so that they do not depend on the learning outcomes of other students. Whereas in PBL, the achievement of learning objectives by a student can be influenced by the results of extracting information from their peers in small groups because the information obtained by each student will be discussed to perfect the knowledge they gain.

Problem solving is not the only goal of the PBL process. Problems or scenarios are used as a stimulus for the learning process to increase knowledge and understanding of the learning objectives set in the curriculum. So that PBL can also be used to facilitate students to gain basic knowledge. Thus, PBL not only facilitates the acquisition of problem solving skills, but also the acquisition of knowledge and understanding, and several other soft skills such as communication, teamwork, independence and responsibility for learning, sharing information and respecting others.

3) Blended Learning RPS / RPB Implementation Plan describes the plan for implementing RPS / RPB Blended Learning in the odd semester of 2020/2021, especially for learning the first half of the semester (Learning before mid-odd semester 2020/2021).

Planning

a) Lecturers identify, define, and classify learning objectives that will be discussed in each PBL learning session.

b) The lecturer arranges, selects or looks for the right scenario to stimulate students to learn the learning objectives that have been set for each PBL session. Scenarios can be in the form of cases, film clips, pictures, news clips and others.

c) The lecturer estimates the schedule for the implementation of the 1st PBL tutorial, the amount of independent study time needed to achieve all the learning objectives set for the PBL session and the schedule for the implementation of the 2nd PBL tutorial.

d) The lecturer prepares a student activity assessment rubric during the tutorial process consisting of attendance, creativity, relevance, attitude and other assessment points deemed necessary.

e) The lecturer divides students into small groups which can consist of 5-10 students per group, each group should ideally be facilitated by a tutor.

f) PBL tutors do not have to be lecturers in the related fields discussed in the scenario. PBL tutors can be anyone who can carry out the role, with the following roles: 
1) Assist the PBL group leader in maintaining group dynamics.

2) Ensuring groups are able to complete the learning objectives that have been set.

3) Ensuring that all students have done their job correctly.

4) Help suggest a format for presenting appropriate independent learning outcomes for group members.

5) Encourage students to evaluate their understanding of the material by asking questions, explaining the material in their own words with pictures and schemes.

6) Provide feedback to students regarding their participation in the tutorial process and regarding the achievement of learning objectives.

Implementation

PBL tutorials are done in a number of ways. The PBL model in the Undergraduate Program of Midwifery, Faculty of Medicine, Andalas University is seven jumps. For each module, students can be given a handbook containing scenarios, while learning resources or materials are given at the right time according to the progress of the tutorial. The PBL implementation steps are as follows:

1) Students are welcome to choose a seat each on a chair that has been arranged in such a way as to facilitate group discussion.

2) Students select a group leader who will act as discussion moderator, and two scribes to record the discussion on paper sheets and on the board. A role is played for each scenario. A flip chart or an appropriate whiteboard should be used to record the discussion process.

3) At the beginning of the session, depending on the type of scenario, one student reads the scenario to all group members or each student reads the scenario separately. If the trigger or scenario is a real patient in the ward, clinic or operating room then students may be asked to take a clinical history or identify any abnormal physical signs before the group moves to the tutorial room.

The stages of the seven jumps are as follows:

Step 1: Identify and explain the unfamiliar terms encountered in the scenario, the scribe notes a glossary of terms that remain unexplained after discussion.
Step 2: Defining the problem or problem to be discussed, students may have different views on the problem, but all must be considered, the scribe notes a list of agreed problems.

Step 3: "Brainstorming" is a session to discuss a problem that has been agreed to be discussed. Students discuss possible explanations or hypotheses that will explain the problem set in step 2, using the knowledge they already have. Students work together by using their respective knowledge and identifying areas of knowledge that have not been properly explained or not sufficiently explained. The clerk records all the results of the discussion.

Step 4: Conduct a review of the discussion reviews in steps 2 and 3 . Then organize the explanations into negative solutions, which are restructured in the form of a schema.

Step 5: Formulate learning objectives, groups reach consensus on learning objectives, tutors ensure learning objectives are focused, achievable, comprehensive and precise.

Step 6: Self-study. All students collect information related to each learning objective. This step is done outside of the PBL tutorial. Lecturers or tutors need to provide sufficient time for students to study independently so that all learning objectives are achieved.

Step 7: Groups come back together for discussion (2nd tutorial discussion). Students share and discuss their independent study results. Tutors evaluate student learning outcomes.

\section{a. Student Assessment Development}

Development of a student assessment system that includes: process assessment, outcome assessment

Selection of assessment techniques according to the level of competence.

4) Evaluation of the Success of Implementing RPS / RPB Blended Learning in facilitating students, its effectiveness is evaluated in the first half of the odd semester 2020/2021 through the following parameters:

a) Learning outcomes.

b) The spread of the final scores.

c) Student response to the development of learning methods and the assessment / assessment system that is applied. 
Development Team

\begin{tabular}{|c|c|c|c|c|c|c|c|}
\hline No. & Name & Duty & last education & Rank / goal & $\begin{array}{l}\text { AA and } \\
\text { Pekerti } \\
\text { Certificate }\end{array}$ & $\begin{array}{l}\text { Other } \\
\text { pedagogica } \\
\text { I training }\end{array}$ & $\begin{array}{l}\text { Previous } \\
\text { Learning } \\
\text { Grant } \\
\text { Experience }\end{array}$ \\
\hline 1 & $\begin{array}{l}\text { Bd.Yulizawati, } \\
\text { SST., M.Keb }\end{array}$ & $\begin{array}{l}\text { Block } \\
\text { Coordinator }\end{array}$ & $\begin{array}{l}\text { Masters in } \\
\text { Midwifery }\end{array}$ & $\begin{array}{l}\text { Administrator s / } \\
\text { IIIC }\end{array}$ & There is & $\begin{array}{l}\text { PBL } \\
\text { Midwife } \\
\text { Professional } \\
\text { Education } \\
\text { Curriculum } \\
\text { Training }\end{array}$ & $\begin{array}{l}\text { PTK LP3M } \\
\text { Unand 2017, } \\
2018,2019 \\
\text { Grant for SCL } \\
\text { Learning } \\
\text { Methods and } \\
\text { Learning } \\
\text { Materials } \\
\text { from the } 2016 \\
\text { Directorate } \\
\text { General of } \\
\text { Belmawa } \\
\text { Kemenristekdi } \\
\text { kti }\end{array}$ \\
\hline 2 & $\begin{array}{l}\text { Miranie } \\
\text { Safaringga, } \\
\text { SST., M.Keb }\end{array}$ & Member & $\begin{array}{l}\text { Masters in } \\
\text { Midwifery }\end{array}$ & $\begin{array}{l}\text { Young } \\
\text { Administrator } \\
\text { / IIIb }\end{array}$ & There is & There is & $\begin{array}{l}\text { PTL LP3M } \\
\text { Unand } \\
2019 \\
\text { (Member } \\
\text { ) }\end{array}$ \\
\hline
\end{tabular}

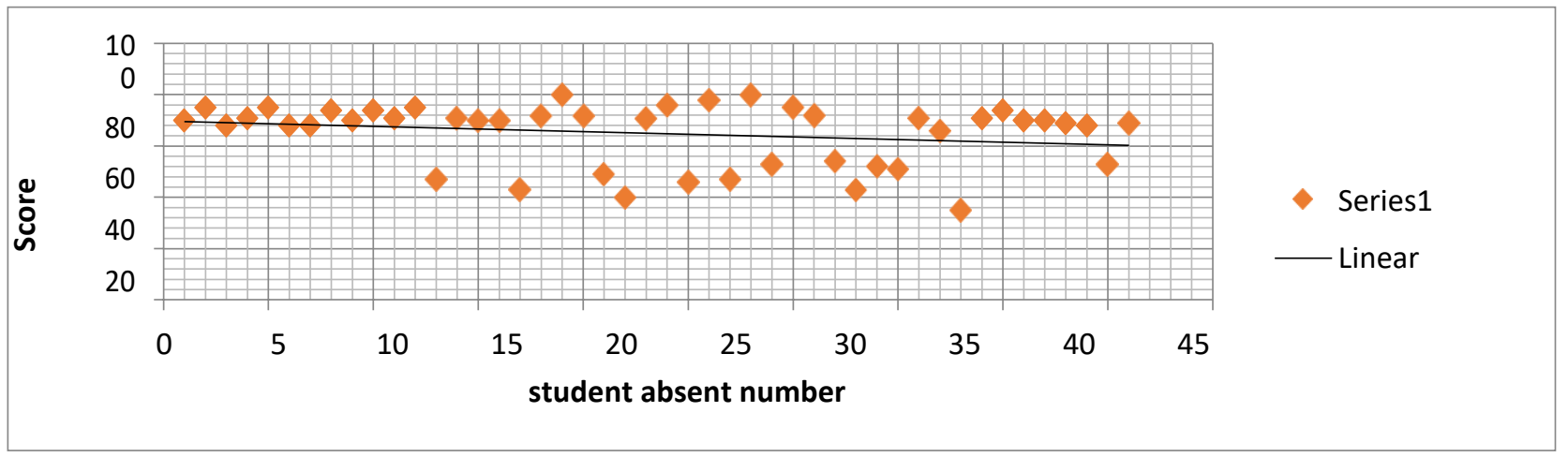

\section{RESULTS AND DISCUSSION}

Distribution of Final Score in the Previous Semester

Distribution of Block 3B Value for 2019/2020 FY (Previous year value)

Analysis of problems in the achievement of student learning outcomes in terms of the selection and application of current student learning and assessment methods, ends with a description of the research objectives

Blended learning is a learning method that combines the advantages of face-to-face learning (offline) with the advantages of online learning in order to achieve graduate learning outcomes. In the learning mix, students not only gain learning experience when accompanied by lecturers in class or outside the classroom, but also gain a wider learning experience independently. When studying in class with lecturers, students get learning materials and learning experiences, good practices, examples, and direct motivation from the lecturer. Meanwhile, when studying online students will be able to control their own learning time, can study anywhere, and are not tied to the teaching methods of the lecturer. The learning material is richer.

Learning Outcomes Attitude 
a. Be devoted to God Almighty and able to show a religious attitude;

b. Upholding human values in carrying out duties based on religion, morals and ethics;

c. Contributing to the improvement of the quality of life in society, nation, state, and progress of civilization based on Pancasila;

d. Acting as citizens who are proud and passionate about the country, have nationalism and a sense of responsibility to the state and nation;

e. Respect the diversity of cultures, views, religions and beliefs, as well as the original opinions or findings of others;

f. Work together and have social sensitivity and care for the community and the environment;

g. Obeying the law and discipline in public and state life;

h. Internalizing academic values, norms, and ethics;

i. Demonstrate an attitude of responsibility for work in their field of expertise independently; and

j. Internalizing the spirit independence, struggle, and entrepreneurship.

General Skills

a. Able to apply logical, critical, systematic, and innovative thinking in the context of the development or implementation of science and knowledge technology that pay attention to and apply humanities values in accordance with their fields of expertise;

b. Able to show independent, quality, and measurable performance;

c. Able to assess development implications or implementation of technology science that pays attention to and applies humanities values according to their expertise based on scientific principles, procedures and ethics in order to produce solutions, ideas, designs or art criticism, compile scientific descriptions of the results of their studies in the form of a thesis or final project report, and upload them on the page College;

d. Compile a scientific description of the results of the study mentioned above in the form of a thesis or final project report, and upload it on the college page;

e. Able to make decisions appropriately in the context of problem solving in their area of expertise, based on the results of analysis of information and data;

f. Able to maintain and developing networks with mentors, colleagues, colleagues both inside and outside the institution;

g. Able to be responsible for the achievement of group work results and to supervise and evaluate the completion of work assigned to workers who are under their responsibility;

h. Able to carry out the self-evaluation process of the work group under their responsibility, and able to manage learning independently; and

i. Capable of documenting, storing, securing, and recovering data to ensure validity and prevent plagiarism.

Special skill

a. Care provider

b. Communicator

c. Community Leader

d. Decision Maker

e. Manager

At the end of the module students are able to explain the basic concepts of childbirth care, physical and psychological changes in childbirth, stage I, stage II, stage III and stage IV labor. Carry out assessments of mothers who give birth, determine planning, implementation and evaluation of delivery, and documentation of midwifery care at delivery.

Based on the definition of blended learning that has been described, this paper will discuss in more depth how the position and role of using this mixed learning strategy in improving the quality of education, especially in Indonesia. The complexity of the reasons for Indonesian education to find solutions and alternative solutions is the goal why this mixed learning is developed. Armed with an initial understanding of the basic concepts of blended learning, the author will try to present the current learning conditions by presenting blended learning as an innovation in the world of learning in Indonesia to overcome the problems that are currently being faced.

This study compares the level of knowledge of Block 3B students regarding Midwifery Care in Normal Delivery between 2018 and 2019 classes, in the 2019 class a new curriculum has been implemented, namely the 2018-2022 curriculum (attached). This study also looked at the comparison between the pre-test and post- test scores.

Table 1. Comparison of the knowledge of 2018 and 2019 class students

\begin{tabular}{|c|c|c|c|c|c|}
\hline \multirow[t]{3}{*}{$\begin{array}{l}\text { Value } \\
\text { Range }\end{array}$} & \multicolumn{2}{|c|}{$\begin{array}{l}\text { Class } \\
2018 \\
\end{array}$} & \multicolumn{2}{|c|}{$\begin{array}{l}\text { Class of } \\
2019\end{array}$} & \multirow[t]{3}{*}{$\mathrm{P}$ value } \\
\hline & & $\%$ & $\mathrm{f}$ & $\%$ & \\
\hline & \multicolumn{4}{|l|}{$\mathrm{f}$} & \\
\hline $85-100$ & 0 & 0 & 0 & 0 & \\
\hline $80-84$ & 0 & 0 & 0 & 0 & \\
\hline $75-79$ & 33 & 6 & 7 & 16 & \\
\hline $70-74$ & 12 & 23 & 19 & 42 & \\
\hline $65-69$ & 22 & 42 & 17 & 38 & \\
\hline $60-64$ & 10 & 19 & 1 & 2 & \\
\hline $55-59$ & 3 & 6 & 0 & 0 & \\
\hline $50-54$ & $\underline{2}$ & $\underline{4}$ & $\underline{1}$ & $\underline{2}$ & \\
\hline
\end{tabular}


Table 2. Comparison of the 2019 class of student knowledge between before and after research with Blended Learning

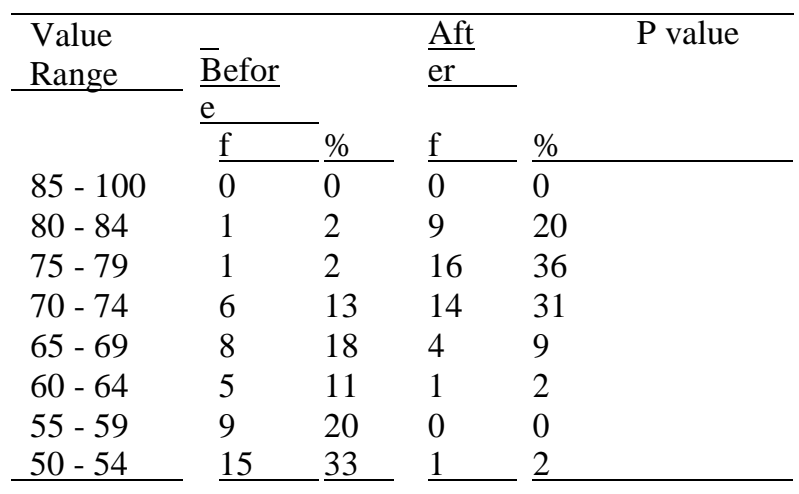

The results of the calculation showed that the majority of students in class 2018 had a value range between $65-95$, namely $42 \%$ of 53 people. Then the same research was carried out on students of class 2019 , the results showed that the majority of students had a value range of 70-74, namely $42 \%$ of 45 people.

The results of calculations before applying the student center learning (CTL) learning method with the problem-based learning (PBL) approach through blended learning, obtained the majority student scores in the range 55-59 with a total of 9 people $(20 \%)$ while after being given treatment, student scores increased by the majority in the range $75-79$, namely 16 people $(36 \%)$

Class 2019 students both use the student center learning (STL) learning method with a problem based learning (PBL) approach through blended learning, namely by using several methods, including tutorials, plenary, topic discussion, independent study, practicum and introductory lectures. the process includes using the online method using the Ilearn application that has been facilitated by academics. However, what is different in this research is that the 2019 class uses the Small Group Discussion (SGD) method on topic discussion learning, where students consist of 8-10 people and 1 facilitator lecturer, while in the 2018 class using a large class system where students are divided into 5 groups and 1 facilitator.

Each student and lecturer previously has an account in order to access Ilearn. In Ilearn, the lecturer acts as a provider of teaching materials that can be uploaded to the account of the lecturer concerned, then at the specified time, students will access their ilearn account and enter the part of the course they want to study at that time. In Block 3B, students on their Illegal account can access in the form of block guides, scenarios as material for turorial discussions and teaching materials in Introductory Lectures by each lecturer who gives lecturers. This teaching material can be in the form of modules, videos or podcasts so that it is more attractive to students and can be accessed from their respective places without having to face to face.

This is in line with the research results of Lutfiasari D \& Prasetyanti DK (2016), there is an effect of the use of problem-based learning methods on partograph filling skills. The PBL learning method can be an alternative learning method in the partograph sub-chapter of the Maternity and Newborn Baby Care course.

Research by Renityas, NN (2015), there is a significant difference with different test results $(\mathrm{P}=$ 0.014) between student participation using a problembased learning model with class group discussions on the pregnancy midwifery care course. Where the PBL model has a better learning participation rate than class group discussions, Problem Based Learning through blended learning is effective in increasing student learning participation.

So far, a popular learning strategy in Indonesia is traditional class-based learning (classical) using the lecture method. In classical learning, the student learning process is bound by the dimensions of time and space which require students to be in the same space and time as their classmates and lecturers. While the use of the lecture method will lead students to be less honed because they are not accustomed to thinking outside the context conveyed by the lecturer and become passive in choosing additional learning sources outside of the learning resources provided by the lecturer.

In fact, lecturers as not the only source of learning, especially in today's digital era, can be obtained relatively easily through the use of ICT (Information and Communication Technology). This condition will cause students to be less active and creative in developing and exploring learning from various sources. The implication is that graduates who are formed will not be independent and confident because they feel dependent on learning activities that originate from lecturers alone (Widiara, 2019).

Furthermore, in the research journal by Annisa Ratna Sari (2013), another impact of using classical learning concepts with the lecture method will cause students' critical thinking skills to become less honed because students are not accustomed to thinking outside the context conveyed by the lecturer and become passive in choosing additional learning resources outside the learning resources provided by the lecturer.

Therefore, the blended learning strategy is an alternative in improving student learning outcomes. The combination of classical learning added with the use of the internet becomes a supplement in increasing student 
achievement. This is because the resulting pedagogy is better, increased access and flexibility, and increased cost of benefits (Annisa, 2013: 34).

The addition of learning innovations will generate independence and confidence in students who have tried to find and explore learning resources not only from lecturers. Student independence plays an important role in learning success.

Sandi (2012) states that students who have high independence excel in blended learning that is more student-centered. Therefore, increasing student independence is something critical in improving learning outcomes that need to be the attention of lecturers and other educational researchers.

Various studies have also shown that blended learning is more effective than conventional learning with face-to-face systems or with the e-learning system or online learning. This level of effectiveness is supported by the advantages possessed by blended learning systems, as follows:

1. Delivery of learning can be carried out anytime and anywhere by utilizing the internet network system.

2. Students have the freedom to study materials or teaching materials independently by utilizing teaching materials stored online.

3. Discussion activities take place online / offline and take place outside of class hours, discussion activities take place both between students and lecturers and between students themselves.

4. Teachers can manage and control the learning carried out by students outside of students' lesson hours.

5. Teachers can ask students to review the subject matter before face-to-face learning takes place by preparing support tasks.

6. The target for achieving teaching materials can be achieved in accordance with the targets set

7. Learning becomes flexible and not rigid

Of course, learning with the concept of combination

/ blending in addition to having the advantages above also has drawbacks, including:

1. Teachers need to have skills in conducting elearning

2. Teachers need to prepare time to develop and manage the learning system of the e-learning, such as developing material, preparing assessments, conducting assessments, and answering or giving statements in forums delivered by students.

3. Teachers need to prepare digital references as a reference for students and digital references that are integrated with face-to-face learning
4. Inequality of supporting facilities and infrastructure and low understanding of technology.

5. Learning strategies are needed by teachers to maximize the potential for blended learning

In a study conducted by Manggabari in 2016, learning using the blended learning method was proven to increase student learning motivation at SMAN 1 Patpetua, Wajo Regency. which uses the Blended Learning learning model which is 3.4 higher than the average score of student motivation in the control class using direct learning, namely 2.7. This shows that the motivation of students in the control class is lower than the experimental class. The level of student motivation also affects student learning outcomes or student achievement.

Based on the results of the discussion above, it can be concluded that blended learning has a positive impact on increasing the value and motivation of student learning in Block 3B.

\section{CONCLUSION}

Based on the results of the discussion above, it can be concluded that blended learning has a positive impact on increasing the value and motivation of student learning in Block $3 \mathrm{~B}$. The results of the calculation showed that the majority of students in class 2018 had a value range between $65-95$, namely $42 \%$ of 53 people. Then the same research was carried out on students of class 2019, the results showed that the majority of students had a value range of 70-74, namely $42 \%$ of 45 people. The results of calculations before applying the student center learning (CTL) learning method with the problem-based learning (PBL) approach through blended learning, obtained the majority student scores in the range 55-59 with a total of 9 people (20\%) while after being given treatment, student scores increased by the majority in the range $75-79$, namely 16 people (36\%).

Blended learning is a learning method that combines the advantages of face-to-face learning (offline) with the advantages of online learning in order to achieve graduate learning outcomes. In the learning mix, students not only gain learning experience when accompanied by lecturers in experience independently. When studying in class with lecturers, students get learning materials and learning experiences, good practices, examples, and direct motivation from the lecturer. Meanwhile, when studying online students will be able to control their own learning time, can study anywhere, and are not tied to the teaching methods of the lecturer. The learning material is richer.

So it can be concluded that the blended learning method is more effectively applied in the student learning process because it is proven to increase students value. 


\section{AUTHORS' CONTRIBUTIONS}

The author's contribution are to play a role in curriculum development, curriculum revision, and improvement of graduate outcomes.

\section{ACKNOWLEDGMENTS}

Alhamdulillah, praise be to the presence of Allah SWT who Most Merciful and Most Compassionate for mercy and His grace so that researchers can complete this research on time.

\section{REFERENCES}

[1] Anderson, L., \& Krathwohl, D. (2001). A Taxonomy for Learning, Teaching and Assessing: A Revision of Bloom's Taxonomy of Educational Objectives. New York:Longman.

[2] AUN-QA. (2015). Guide to AUN-QA Assessment at Program Level Version 3.0. Bangkok: ASEAN University Network.

[3] Brookhart, SM, \& Nitko, AJ (2015). Educational assessment of students (7th ed.). New Jersey: Pearson.

[4] Bruner, JS (1977). The Process of Education. United States of America: HARVARD UNIVERSITY PRESS.

[5] Clark, RC, \& Lyons, C. (2010). Graphics for Learning: Proven Guidelines for Planning, 
Designing, and Evaluating Visuals in Training Materials 2nd Edition. San Francisco: Pfeiffer.

[6] Dick, W., Carey, L., \& Carey, JO (2014). The Systematic Design of Instruction (8thed.).

[7] New York: Pearson.

[8] Gagne, RM, Briggs, LJ, \& Wager, WW (1992). Principles of Instructional Design (4th ed.). New York: Harcourt Brace College Publishers.

[9] Garrison, RD, \& Vaughan, ND (2008). Blended Learning in Higher Education. San Francisco: John Wiley \& Sons, Inc.

[10] Gredler, ME (2011). Learning and Instruction: Theory into Practice (6th ed.). New York: Pearson.

[11] Harden, RM (1999). What is a spiral curriculum? Medical Teacher, 21 (2), 141-143.

[12] Joyce, B., Weil, M., \& Calhoun, E. (2009). Models of Teaching (8th ed.). New Jersey: Pearson Education, Inc.

[13] Kelly, AV (2004). The Curriculum: Theory and Practice (5th ed.). London: Sage Publications.

[14] Khataybeh, A., \& Ateeg, NA (2011). How "Writing Academic English" Follows Bruner's Spiral Model in Curriculum Planning. Journal of Emerging Trends in Educational Research and Policy Studies, 127-138.

[15] Marsh, CJ (2004). Key Concepts for Understanding Curriculum (3 ed.). New York: RoutledgeFalmer.

[16] Marzano, RJ, \& Kendall, JS (2007). The New Taxonomy of Educational Objectives. California: A Sage Publications Company.

[17] Medical School Undergraduate Office. (2014, January 1). Dundee MBChB Medicine Program. Retrieved June 29, 2016, from School of Medicine: Part of the University of

Dundee:http://medicine.dundee.ac.uk/dundeembchb- medicine-program

[18] Minister of Education and Culture of the Republic of Indonesia. (2013, June 10). Application of the Indonesian National Qualifications Framework for Higher Education. Regulation of the Minister of Education and Culture of the Republic of Indonesia Number 73 of 2013.
[19] Jakarta, Jakarta, Indonesia: Ministry of Education and Culture of the Republic of Indonesia.

[20] Minister of Research, Technology and Higher Education of the Republic of Indonesia. (2015, December 28). National Higher Education Standards. Regulation of the Minister of Research, Technology and Higher Education of the Republic of Indonesia Number 44 of 2015. Jakarta, Jakarta, Indonesia: Ministry of Research, Technology and Higher Education of the Republic of Indonesia.

[21] Minister of Research, Technology and Higher Education of the Republic of Indonesia. (2015, May 8).

[22] About the Strategic Plan of the Ministry of Research, Technology and Higher Education 2015-2019. Regulation of the Minister of Research, Technology and Higher Education of the Republic of Indonesia Number 13 of 2015. Jakarta, DKI, Indonesia: Minister of Research, Technology and Higher Education of the Republic of Indonesia.

[23] Minister of Research, Technology and Higher Education of the Republic of Indonesia. (2018, October 30). Amendments to the Regulation of the Minister of Research, Technology and Higher Education Number 44 of 2015 concerning National Higher Education Standards. Regulation of the Minister of Research, Technology and Higher Education of the Republic of Indonesia Number 50 of 2018. Jakarta, DKI, Indonesia: Director General of Legislation, Ministry of Law and Human Rights, Republic of Indonesia.

[24] Ornstein, AC, \& Hunkins, FP (2004). CURRICULUM: Foundations, Principles, and Issues (4th ed.). New York: Pearson.

[25] Ornstein, AC, \& Hunkins, FP (2014). CURRICULUM: Foundations, Principles, and Issues (6th ed.). New York: Pearson.

[26] Guidelines for Developing Higher Education Curriculum in the Industrial Era 4.0 in 2018, Directorate General of Learning and Student Affairs, Ministry of Research, Technology and Higher Education

[27] President of the Republic of Indonesia. (2012, January 17). Indonesian National Qualifications Framework. Presidential Regulation of the Republic of Indonesia Number 8 of 2012. 
Jakarta, Jakarta, Indonesia: Minister of Law and Human Rights of the Republic of Indonesia.

[28] President of the Republic of Indonesia. (2012, August 10). Higher education. Law Number 12 of 2012. Jakarta, Jakarta, Indonesia: Ministry of State Secretariat of the Republic of Indonesia.

[29] Taba, H. (1962). Curriculum Development: Theory and Practice. USA: Harcourt Brace Jovanovich, Inc.

[30] Work team. (2005). Competency Based Curriculum for Science Fields. Jakarta: Directorate General of Higher Education Ministry of National Education.

[31] Work team. (2005). Questions and Answers Regarding Competency-Based Curriculum in Higher Education. Jakarta: Directorate General of Higher Education - Ministry of National Education.

[32] Work team. (2005). Questions and Answers Regarding the Material Development Unit and Learning Process in Higher Education. Jakarta: Directorate General of Higher Education Ministry of National Education.

[33] Tyler, RW (2013). Basic Principle of Curriculum and Instruction. Chicago and London: The University of Chicago Press.

[34] Zais, RS (1976). Curriculum: Principle and Foundations. New York: Harper \& Row. 